\title{
Portabilitatea datelor cu caracter personal, prin prisma dispoziţiilor RGDP şi ale Directivei 2019/770: este gambitul reginei mutarea de deschidere adecvată?
}

\author{
Portability of Personal Data, From the Perspective \\ of the GDPR and Directive 2019/770 Provisions: \\ Is the Queen's Gambit the Right Opening?
}

\author{
Juanita Goicovici ${ }^{1}$
}

Rezumat: Studiul abordează problematica portabilităţii datelor cu caracter personal, în perimetrul exercitării dreptului persoanei vizate de acces la datele cu caracter personal colectate şi prelucrate de către operatorii de date cu caracter personal, astfel cum este conturat în textul art. 15 din Regulamentul General nr. 679 din 27 aprilie 2016 privind protecţia persoanelor cu privire la prelucrarea datelor cu caracter personal şi libera circulaţie a acestor date. Exercitarea dreptului la portabilitatea datelor cu caracter personal nu implică doar efecte insulare, ci antamează efecte de tip arhipelag, prin prisma faptului că se poziţionează în prima linie a exercitării efective a altor drepturi esenţiale ale persoanei vizate, în optica dispoziţiilor GDPR şi ale Directivei 2019/770, condiţionând implicit, într-o măsură considerabilă, exercitarea dreptului de acces la datele cu caracter personal, dreptul la rectificare a datelor cu caracter personal şi dreptul de a se opune prelucrării datelor cu caracter personal. Controlul exercitat de persoana vizată asupra prelucrării datelor cu caracter personal şi participarea activă a persoanei vizate la actualizarea preferinţelor sale în ceea ce priveşte consimţământul la prelucrarea datelor cu caracter personal, inclusiv decizia de a transfera datele cu caracter personal către un alt operator îşi găsesc expresia normativă în binomul reprezentat de dreptul de acces al persoanei vizate şi dreptul la portabilitatea datelor. Portabilitatea datelor necesită punerea în aplicare a standardelor tehnice pertinente, în ceea ce priveşte adecvarea mecanismului care vizează facilitarea transferului de date între operatori, inclusiv prin prisma capacităţii de a exporta datele utilizatorului într-un fişier digital accesibil utilizatorului, promovând astfel interoperabilitatea, precum şi facilitarea identificării datelor şi controlul efectiv al persoanei vizate asupra procesării datelor cu caracter personal.

Cuvinte-cheie: portabilitate; date personale; drept de acces; drept de restricţionare; drept de opoziţie

${ }^{1}$ Lector univ. dr., Facultatea de Drept, Universitatea „Babeș-Bolyai” din Cluj-Napoca, e-mail: juanita.goicovici@law.ubbcluj.ro. Textul studiului preia argumentele susținute în cadrul Conferinței internaționale „Perspective juridice asupra Internetului. Spațiul virtual, ultima frontieră? Încheierea și executarea contractelor”, ediția a 5-a, Iași, 30-31 oct. 2021. 


\begin{abstract}
The study addresses the issue of the personal data portability, in the perimeter of the exercising of the data subject's right of access to personal data collected and processing by personal data controllers, as outlined in the text of art. 15 of Regulation no. 679 of 27 April 2016 on the protection of individuals with regard to the processing of personal data and on the free movement of such data. The exercise of the right of personal data portability does not imply merely insular effects, since it consequentially engages archipelago effects, as it is at the forefront of the effective exercise of other essential rights of the data subject, in the light of the GDPR and Directive 2019/770 provisions, implicitly conditioning, to a considerable extent, the exercise of the right of access to personal data, the right to rectification of personal data and the right to oppose the processing of personal data. The subject's control exercised over the personal data processing concerning the active participation of the data subject in updating his / her preferences in terms of consenting to personal data processing, including the decision to port the personal data to another controller, find their normative expression in the binomen represented by the data subject's right of access and the right of data portability. Data portability requires the implementing of pertinent technical standards, in terms of adequacy and appropriateness of mechanism aimed at the facilitating of the transfer from one data controller to another, such as the ability to export user data into a user-accessible local file, thus promoting interoperability, as well as facilitating searchability and data subject's effective control over data processing.
\end{abstract}

Keywords: portability; personal data; right of access; right of restriction; right of opposition

\title{
1. Remarci introductive
}

Ipostaziindu-se ca expresie a dreptului persoanei vizate de a-şi retrage oricând, în orice moment, consimţământul furnizat voluntar cu privire la colectarea şi prelucrarea datelor cu caracter personal care o privesc, calibrată ca mecanism de $\mathrm{control}^{2}$ al persoanei vizate asupra propriilor date personale, portabilitatea datelor

${ }^{2}$ A se consulta, pentru detalii, P. de Hert, V. Papakonstantinou, G. Malgieri, L. Beslay, I. Sanchez, The Right to Data Portability in the GDPR: Towards User-Centric Interoperability of Digital Services, Computer Law \& Security Review, 2018, pp. 193-203, [Online] la https://ssrn.com/abstract=3447060, accesat 08.11.2021; A. de Streel, J. Kraemer, P. Senellart, Making Data Portability More Effective for the Digital Economy (June 14, 2021), [Online] la https://ssrn.com/abstract=3866495, accesat 08.11.2021; D. Gill, W. Kerber, Data Portability Rights: Limits, Opportunities, and the Need for Going Beyond the Portability of Personal Data (October 11, 2020), [Online] la https://ssrn.com/ abstract=3715357, accesat 08.11.2021; I. Graef, The Opportunities and Limits of Data Portability for Stimulating Competition and Innovation, Competition Policy International, Antitrust Chronicle November 2020 (II), [Online] la https://ssrn.com/abstract=3740185, accesat 08.11.2021; P. Aertgeerts, Shaping Fundamental Rights: The Right to Data Portability, the EU Legislator and the Normative Foundations of the Fundamental Right to Data Protection (November 6, 2019), [Online] la https://ssrn.com/abstract=3497791, accesat 08.11.2021; A. Alberini, Y. Benhamou, Data Portability and Interoperability: An Issue that Needs to Be Anticipated in Today's It-Driven World (August 1, 2017), [Online] la https://ssrn.com/abstract=3038877, accesat 08.11.2021; G. Araújo Souto, Data Portability: a Necessary Right for Users and Competitors of Digital Platforms (October 12, 2018), [Online] la https://ssrn.com/abstract=3293056, accesat 08.11.2021. 
personale descrie mutabilitatea acestor date, posibilitatea de a fi transferate către un alt operator la solicitarea persoanei vizate, cu corolarul posibilităţii de a reutiliza datele personale într-un alt context digital ${ }^{3}$.

Parcimonios în abordare, textul art. 20 din RGDP descrie aceste prerogative ca referindu-se la faptul că „Persoana vizată are dreptul de a primi datele cu caracter personal care o privesc şi pe care le-a furnizat operatorului într-un format structurat, utilizat în mod curent şi care poate fi citit automat şi are dreptul de a transmite aceste date altui operator, fără obstacole din partea operatorului căruia i-au fost furnizate datele cu caracter personal”, în cazurile expres prevăzute de art. 20, alin. (1), lit. a).-b). din Regulamentul General.

Descompus în prerogativele supraetajate conferite persoanei vizate, dreptul la portabilitatea datelor personale implică: (i) dreptul titularului de a primi datele personale într-un format structurat (sau aşa-numita prerogativă a persoanei vizate de prelucrare, de a recupera informaţiile cu caracter personal pe care le-a furnizat unui operator, într-o formă structurată, utilizată curent, lizibilă automat), persoană care poate păstra informaţiile pentru uz personal ori le poate transmite unui alt operator; (ii) dreptul de a transmite datele unui alt responsabil / operator, care se exercită fără ca operatorul de date precedent să poată formula o opoziţie, în acest mod, persoana vizată păstrând controlul asupra propriilor date; astfel, dreptul la portabilitate încurajează persoanele vizate să îşi recupereze datele cu caracter personal şi să le reutilizeze; (iii) dreptul la portabilitatea datelor se ipostaziază, simultan, ca expresie a dreptului persoanei vizate de retractare a consimţământului la prelucrarea datelor sale cu caracter personal ${ }^{4}$, furnizate în primă fază operatorului de date în vederea prelucrării, în baza unui consimţământ de tip opting-in, componenta consimţământului opting-out fiind esenţială în economia prelucrării datelor conform dispoziţiilor RGDP, fondată pe consimţământul persoanei vizate. Precaritatea obţinerii acordului persoanei vizate cu privire la prelucrarea datelor

${ }^{3}$ C. Jugastru, Dreptul la portabilitatea datelor, Revista Universul Juridic, [Online] la http://revista.universuljuridic.ro/dreptul-la-portabilitatea-datelor/, accesat 08.11.2021.

${ }^{4}$ Pentru dezvoltări, a se consulta C. Banda, Enforcing Data Portability in the Context of EU Competition Law and the GDPR, MIPLC Master Thesis Series 2017, [Online] la https://ssrn.com/abstract=3203289, accesat 08.11.2021; I. Graef, D. Clifford, P. Valcke, Fairness and Enforcement: Bridging Competition, Data Protection and Consumer Law, International Data Privacy Law, vol. 8, nr. 3/2018, pp. 200-223, [Online] la https://ssrn.com/abstract=3216198, accesat 08.11.2021; J. Belo, P. Macedo Alves, The Right to Data Portability: An In-Depth Look, Journal of Data Protection and Privacy, Vol. 2, nr. 1/2018, pp. 53-61, [Online] la https://ssrn.com/abstract=3541656, accesat 08.11.2021; M. Borghi, Data Portability and Regulation of Digital Markets, CIPPM / Jean Monnet Working Papers, Bournemouth University, 2019, [Online] la https://ssrn.com/abstract=3617792, accesat 08.11.2021; E. Bozdag, Data Portability Under GDPR: Technical Challenges (January 28, 2018), [Online] la https://ssrn.com/ abstract=3111866, accesat 08.11.2021; I. Graef, M. Husovec, J. van den Boom, Spill-Overs in Data Governance: The Relationship Between the GDPR's Right to Data Portability and EU Sector-Specific Data Access Regimes, TILEC Discussion Paper No. DP 2019-005, 2019, [Online] la https://ssrn.com/abstract=3369509, accesat 08.11.2021. 
personale care o privesc, ca şi caracterul eminamente provizoriu al acestui acord asupra colectării şi prelucrării, implică, pentru operatorii de date, obligaţia de a informa utilizatorii cu privire la existenţa dreptului la portabilitate, dublată de obligaţia de a onora cererea de portabilitate a utilizatorului în cel mai scurt timp posibil, însă fără să depăşească o lună de la data solicitării, sau, în cazurile complexe, fără să poată depăşi un interval de trei luni de la data primirii cererii de portare, cu condiţia ca operatorul să informeze utilizatorul despre motivele care duc la întârzierea onorării cererii, în termen de o lună, respectiv obligaţia operatorului de a răspunde cererii utilizatorului de portare a datelor / de accesare a acestora într-un format structurat, chiar dacă acest răspuns este unul negativ (de refuz), în ipotezele (limitate) în care refuzul ar fi unul legitim.

Ne propunem, în paragrafele care urmează, să abordăm, mai întâi, prerechizitele exercitării dreptului la portabilitatea datelor, prin prisma controlului exercitat de persoana vizată asupra prelucrării datelor cu caracter personal, precum şi din unghiul elementelor care caracterizează participarea activă, asertivă a persoanei vizate la actualizarea preferinţelor sale în ceea ce priveşte consimţământul la prelucrarea datelor cu caracter personal, inclusiv în ceea ce priveşte decizia de a transfera datele cu caracter personal către un alt operator (i), urmând ca, într-o secţiune distinctă, să ne oprim asupra problematicii suprapunerii parţiale şi a imbricaţiilor semnalate între dispoziţiile art. 20 RGDP şi prevederile Directivei 2019/770 în materia conformităţii conţinutului digital (ii).

\subsection{Portabilitatea datelor cu caracter personal: efecte de tip insular vs. efecte de tip arhipelag}

Calibrată ca prerogativă de control al titularului asupra prelucrării datelor sale personale, portabilitatea datelor se bifurcă în dreptul unei persoane fizice „de a primi datele cu caracter personal care o privesc şi pe care le-a furnizat operatorului într-un format structurat, utilizat în mod curent şi care poate fi citit automat" (i) şi, pe celălalt versant, în dreptul de a transmite aceste date altui operator, fără obstacole nejustificate din partea operatorului căruia i-au fost furnizate datele cu caracter personal (ii), fiind, din start, excluse din sfera materială de incidenţă a acestui drept datele anonimizate sau datele care nu privesc utilizatorul care solicită accesul ${ }^{5}$; datele pseudonimizate (care, prin definiţie, pot fi

${ }^{5}$ Noțiunea de „date furnizate de către utilizator” trebuie interpretată și înțeleasă în mod extensiv, după cum s-a evidențiat în literatura de specialitate, astfel încât s-a admis că aceasta cuprinde toate datele deținute de către operator cu privire la persoana utilizatorului, cu excepția datelor inferate sau derivate. În acest sens, sunt incluse, pe de o parte, datele personale furnizate în mod activ de către utilizator prin mijloacele tehnice puse la dispoziție de către operator, ca, de exemplu, datele privitoare la adresa de e-mail, vârstă, locație, număr de telefon, adresă poștală, nume utilizator, cod numeric personal etc. (a), precum și datele rezultate din activitatea utilizatorului, cum ar fi: datele privind locaţia, pulsul acestuia și valorile tensiunii arteriale, istoricul de căutări pe o pagină web, paginile web accesate etc. După cum s-a subliniat, însă, cu privire la datele inferate sau derivate din datele oferite operatorului de către utilizator, acesta din urmă nu beneficiază de dreptul la 
folosite pentru a identifica utilizatorul, chiar dacă identificarea se face cu ajutorul unor chei de decriptare) fac obiectul dreptului la portarea datelor, pseudonimizarea nereprezentând per se un obstacol în calea exercitării acestor prerogative. Obligaţiile operatorului de date, aflate în corelaţie cu exerciţiul dreptului la portabilitate, se defalcă în obligaţia de a informa utilizatorii cu privire la existenţa dreptului la portabilitate (a), obligaţia de a pune la dispoziţia utilizatorului, la cererea acestuia, o versiune a datelor furnizate de către acesta într-un format accesibil şi reutilizabil (b), operatorul fiind, de asemenea, obligat să onoreze cererea utilizatorului în cel mai scurt timp posibil, însă fără să depăşească o lună de la data solicitării, sau, în cazurile complexe, nu mai mult trei luni de la momentul amintit, cu condiţia ca operatorul să informeze utilizatorul despre motivele care conduc la întârzierea onorării cererii în termenul de o lună (c); operatorului de date îi incumbă, totodată, obligaţia să răspundă cererii utilizatorului, chiar dacă acest răspuns este unul negativ, de refuz al accesului la date într-un format portabil ${ }^{6}$ (d); se cuvine reamintit că operatorul poate refuza onorarea unei astfel de cereri a utilizatorului dacă aceasta este nefondata sau dacă are un caracter repetitiv la intervale nerezonabile de timp (ori le poate onora contra unui cost rezonabil); este util de menţionat, de asemenea, că aceste cereri nu pot fi considerate ca fiind excesive dacă, prin natura activităţii sale, operatorul oferă servicii de informare sau procesare automată a datelor personale. $\mathrm{Cu}$ titlu de principiu, operatorul de date trebuie să onoreze cererile de acces la date şi de portare în mod gratuit ${ }^{7}$ (cu excepţia

portabilitate. Pentru detalii, a se consulta I. Graef, M. Husovec, N. Purtova, Data Portability and Data Control: Lessons for an Emerging Concept in EU Law, German Law Journal, vol. 19, nr. 6/2018, pp. 1359-1398, Tilburg Law School Research Paper No. 2017/22, [Online] la https://ssrn.com/abstract=3071875, accesat 08.11.2021; J. Hurwitz, Digital Duty to Deal, Data Portability, and Interoperability, The Global Antitrust Institute Report on the Digital Economy 28, 2020, [Online] la https://ssrn.com/abstract=3733744, accesat 08.11.2021; T. Ke, K. Sudhir, Privacy Rights and Data Security: GDPR and Personal Data Driven Markets (July 5, 2020), [Online] la https://ssrn.com/abstract=3643979, accesat 08.11.2021; J. Kraemer, Personal Data Portability In The Platform Economy: Economic Implications And Policy Recommendations, Journal of Competition Law \& Economics, 2020, [Online] la https://ssrn.com/abstract=3742771, accesat 08.11.2021.

${ }^{6}$ A se vedea M. Leistner, The Existing European IP Rights System and the Data Economy - An Overview With Particular Focus on Data Access and Portability, în J. Drexl (ed.), „Data access, Consumer Protection and Public Welfare", Nomos, 2020, [Online] la https://ssrn.com/abstract=3625712, accesat 08.11.2021; P. Leonard, Regulatory Trends and Emerging Practices in Access to Customer Data, Portability and Data Sharing in the Financial Services Sector (December 3, 2017), [Online] la https://ssrn.com/ abstract=3154275, accesat 08.11.2021;

${ }^{7}$ A. Lisievici, Dreptul la portabilitatea datelor potrivit Regulamentului General privind Protecția Datelor, în I. Alexe, D.-N. Ploeșteanu, D.-M. Șandru, „Protecția datelor cu caracter personal. Impactul protecției datelor personale asupra mediului de afaceri. Evaluări ale experiențelor românești și noile provocări ale Regulamentului (UE) 2016/679”, Editura Universitară, București, 2017, p. 149-153, [Online] la https://ssrn.com/abstract=3039537, accesat 09.11.2021. 
cazurilor de adresare a unor cereri repetitive, pentru care poate percepe o contraprestaţie echitabilă), operatorul trebuind să ia toate măsurile de siguranţă, astfel încât datele transmise să ajungă în mod sigur (de exemplu prin utilizarea unor encrypt keys) la utilizatorul corect selectat, cu evitarea unor data leaks către persoane care nu sunt titulari ai dreptului de acces, fără ca aceste măsuri de filtrare a accesului ilegal ori de siguranţă să împiedice utilizatorii să îşi exercite drepturile privitoare la portarea datelor cu caracter personal. În ceea ce priveşte selectarea formatului adecvat, Regulamentul General recunoaşte ca format adecvat ${ }^{8}$ orice format electronic, structurat şi codificat într-o manieră care nu limitează procesarea automată sau reutilizarea datelor şi care poate fi recunoscut uşor de către aplicaţiile software, costul impus de onorarea unei astfel de cereri neputând reprezenta un motiv legitim de refuz al accesului la datele cu caracter personal întrun format portabil.

\subsection{Contra-gambitul: portabilitatea datelor în temeiul dispoziţiilor Directivei 2019/770 privind contractele de furnizare de conţinut digital şi de servicii digitale}

După cum rezultă din Considerentul (24) al Directivei 2019/770, datele cu caracter personal pot constitui o contraprestaţie conjuncturală a furnizării conţinutului digital, în legătură cu acest aspect reţinându-se, în cuprinsul considerentului menţionat, că, în esenţă, „conţinutul digital şi serviciile digitale sunt adesea furnizate şi în cazul în care consumatorul nu plăteşte un preţ, ci îi furnizează comerciantului date cu caracter personal". Caracterul de drept fundamental al dreptului la protecţia datelor personale este amintit expressis verbis în textul Considerentului (24) al Directivei 2019/770, cu indicarea explicită a faptului că datelor personale, dacă le poate fi imprimat regimul de bunuri aflate în circuitul civil / comercial ${ }^{9}$, acest regim nu exclude (şi nici nu restrânge) protecţia juridică specială de care se bucură în opoziţie cu statutul altor bunuri incorporale ${ }^{10}$.

${ }^{8}$ A. G. Monteleone, Il Diritto Alla Portabilità Dei Dati. Tra Diritti Della Persona e Diritti Del Mercato, LUISS Law Review, 2/2017, [Online] la https://ssrn.com/abstract=3088984, accesat 08.11.2021; G. Nicholas, Taking It With You: Platform Barriers to Entry and the Limits of Data Portability, Michigan Telecommunications and Technology Law Review, 2020, [Online] la https://ssrn.com/abstract=3550870, accesat 08.11.2021; P. Swire, The Portability and Other Required Transfers Impact Assessment: Assessing Competition, Privacy, Cybersecurity, and Other Considerations, Georgia Tech Scheller College of Business Research Paper No. 3689171, 2020, [Online] la https://ssrn.com/abstract=3689171, accesat 08.11.2021.

${ }^{9}$ A. Metzger, A Market Model for Personal Data: State of Play Under the New Directive on Digital Content and Digital Services (August 4, 2020). în S. Lohsse, R. Schulze, D. Staudenmayer (eds.), „Data as Counter-Performance - Contract Law 2.0?” Münster Colloquia on EU Law and the Digital Economy V, 2020, [Online] la https://ssrn.com/ abstract $=3666805$, accesat 29.11.2021.

${ }^{10}$ In Considerentul (24) al Directivei 2019/770 se reține că: „Deși recunoaște pe deplin că protecția datelor cu caracter personal este un drept fundamental și, așadar, datele cu caracter personal nu pot fi considerate o marfă, prezenta directivă ar trebui să asigure faptul 
Încorsetată între limitele descrise în Considerentul (24), situaţia în care datele cu caracter personal sunt furnizate comerciantului / vânzătorului de conţinut digital fie în momentul încheierii contractului (i), fie ulterior, de exemplu, atunci când consumatorul îşi dă consimţământul ca vânzătorul să utilizeze datele cu caracter personal pe care consumatorul le-ar putea încărca sau le-ar putea crea cu ajutorul conţinutului digital sau al serviciului digital (ii) implică numeroase interogaţii practice, în legătură cu eventuala suprapunere ori prioritizare a invocării dreptului de acces ${ }^{11}$ la datele încărcate, într-un format portabil fie în temeiul prevederilor art. 20 RGDP, fie, dimpotrivă, în temeiul dispoziţiilor specifice incluse în Directiva 2019/770 privind contractele de furnizare a conţinutului digital.

„Gambitul” veritabil la care poate recurge utilizatorul, în aceste cazuri, va presupune invocarea prevederilor art. 20 RGDP dacă doreşte să obţină transmutarea datelor cu caracter personal într-un format portabil până la momentul rezilierii contractului de furnizare a conţinutului digital / serviciilor digitale, moment de la care s-ar putea prevala de dispoziţiile Directivei 2019/770 pentru a obţine portarea datelor / fişierelor încărcate ori create cu ajutorul conţinutului digital contractat, incluzând eventualele date cu caracter personal astfel utilizate.

că, în contextul acestor modele de afaceri, consumatorii au dreptul la măsuri corective contractuale. Prin urmare, prezenta directivă ar trebui să se aplice contractelor în care comerciantul furnizează sau se angajează să furnizeze conținut digital sau un serviciu digital consumatorului, iar consumatorul furnizează sau se angajează să furnizeze date cu caracter personal. Datele cu caracter personal ar putea fi furnizate comerciantului fie în momentul încheierii contractului, fie ulterior, de exemplu, atunci când consumatorul își dă consimțământul ca respectivul comerciant să utilizeze datele cu caracter personal pe care consumatorul le-ar putea încărca sau le-ar putea crea cu ajutorul conținutului digital sau al serviciului digital. Dreptul Uniunii privind protecția datelor cu caracter personal prevede o listă cuprinzătoare de temeiuri juridice pentru prelucrarea legală a datelor cu caracter personal. Prezenta directivă ar trebui să se aplice oricărui contract în care consumatorul furnizează sau se angajează să furnizeze comerciantului date cu caracter personal. De exemplu, prezenta directivă ar trebui să se aplice în cazul în care consumatorul deschide un cont pe o platformă de comunicare socială și pune la dispoziția comerciantului numele și adresa de e-mail, care sunt folosite și pentru alte scopuri decât simpla furnizare a conținutului digital sau a serviciului digital sau respectarea cerințelor legale. Prezenta directivă ar trebui să se aplice, de asemenea, și în cazul în care consumatorul își dă consimțământul ca orice material care constituie date cu caracter personal, cum ar fi fotografiile sau postările pe care le încărcă, să fie prelucrate de comerciant în scopuri de marketing. Totuşi, statele membre ar trebui să dispună de libertatea de a decide dacă sunt respectate dispozițiile de drept intern privind încheierea, existența și valabilitatea contractelor."

${ }^{11} \mathrm{H}$. Vrabec, The Failure of Control Rights in the Big Data Era - Does a Holistic Approach Offer a Solution?, in M. Bakhoum, B. Gallego Conde, M.-O. Mackenordt, G. Surblyte (eds.) „Personal Data in Competition, Consumer Protection and IP Law - Towards a Holistic Approach?”, Berlin Heidelberg: Springer, 2017, [Online] la https://ssrn.com/abstract= 3134745, accesat 08.11.2021; 


\subsection{In unum locum colliguntur: situaţii incluse şi situaţii exceptate din sfera dreptului de a obţine portarea datelor personale}

Controlul exercitat de persoana vizată asupra prelucrării datelor cu caracter personal, ca şi participarea activă, asertivă a persoanei vizate la actualizarea preferinţelor sale în ceea ce priveşte consimţământul la prelucrarea datelor cu caracter personal, inclusiv decizia de a transfera datele cu caracter personal către un alt operator, îşi găsesc expresia normativă în binomul reprezentat de dreptul de acces al persoanei vizate şi dreptul la portabilitatea datelor. Portabilitatea datelor personale este condiţionată, frecvent, de prerechizitele tehnice privind punerea în aplicare a standardelor tehnice pertinente, în ceea ce priveşte adecvarea mecanismului care vizează facilitarea transferului de date între operatori, inclusiv prin prisma capacităţii de a exporta datele utilizatorului într-un fişier digital accesibil utilizatorului, promovând astfel interoperabilitatea, precum şi facilitarea identificării datelor şi controlul efectiv al persoanei vizate asupra procesării datelor cu caracter personal.

Dispoziţiile art. 20 din Regulamentul General indică un triptic de situaţii exceptate din sfera exerciţiului dreptului de a obţine portarea datelor personale. Pe un prim palier, este de semnalat că dreptul la portabilitate se aplică numai datelor aflate în posesia operatorului la momentul procesării cererii de acces / de portare, astfel încât devine un truism aserţiunea conform căreia, dacă persoana vizată şi-a exercitat anterior dreptul la uitare (dreptul la ştergerea datelor) în temeiul art. 17 RGDP, titularul nu poate adresa simultan / ulterior o solicitare de portare a datelor. Acelaşi efect poate fi semnalat şi pentru datele care au fost anonimizate şi nu mai aparţin unei persoane identificabile, la momentul înregistrării cererii de acces la date într-un format portabil. Observaţia enunţată în literatura de specialitate ${ }^{12}$ este pertinentă şi merită accentuată: operatorului de date nu îi incumbă, însă, automat obligaţia ştergerii datelor cu caracter personal, ca urmare a primirii solicitării de portare, în măsura în care şi atât timp cât datele respective sunt necesare pentru executarea în continuare a contractului, după cum nu îi revine operatorului nici obligaţia de a menţine ${ }^{13}$ datele cu caracter personal peste durata stabilită iniţial,

12 A se vedea S. Turner, J. Galindo Quintero, J. Lis, L. Tanczer, The exercisability of the right to data portability in the emerging Internet of Things (IoT) environment (September 26, 2021), [Online] la SSRN: https://ssrn.com/abstract=3931040, accesat 08.11.2021; S. Vezzoso, Competition Policy in Transition: Exploring Data Portability's Roles, 15th ASCOLA Conference, 25-27 June 2020, [Online] la https://ssrn.com/abstract=3634736, accesat 08.11.2021.

${ }^{13}$ În literatura de specialitate, s-a subliniat că: "A final remark should be dedicated to the balancing provisions of Article 20(3). It may happen that data controllers, in order to comply with users' requests of data portability, could adopt specific technologies (data trackers, personal data identifiers, etc.) in processing operations that could appear as unfeasible for a full erasure of personal data. Another risk might be that, in order to guarantee a full exercise of the right to data portability to all users, data subjects whose data are inseparable from other subjects' data could be prevented from having their data erased. In all these cases, Article 20(3) 
corelată cu scopurile prelucrării (în aşteptarea unor potenţiale solicitări de portare); de asemenea, este deja un truism faptul că operatorului de date nu îi revine obligaţia de a utiliza formate digitale compatibile cu ale altor operatori. Pe celălalt versant al discuţiei, dreptul la portabilitate nu poate interfera cu o sarcină a prelucrării datelor îndeplinită de operator în interes public. În cel de-al treilea rând, portabilitatea nu va afecta negativ drepturile şi libertăţile altora, ca limită enunţată expres în cuprinsul art. 20 RGDP.

Recognoscibilă în special prin faptul că datele cu caracter personal a căror portare este solicitată sunt plasate, la acel moment, în interconectivitate cu datele personale ale altor persoane vizate ${ }^{14}$ (începând cu exemplul clasic al unei imagini în care figurează mai multe persoane ori exemplul unui raport de activitate procesat de angajator în care au fost evaluate performanţele mai multor salariaţi etc. ${ }^{15}$ ), cea de a treia excepţie de la regula portabilităţii datelor cu caracter personal intervine în ipoteza în care persoana vizată, care a solicitat portarea datelor, a furnizat aceste date operatorului iniţial ${ }^{16}$, iar un posibil răspuns afirmativ ar putea implica lezarea drepturilor altor persoane ori, cel puţin, bruscarea într-o manieră nerezonabilă ori inadecvată a aşteptărilor rezonabile ale celorlalte persoane vizate implicate. În acest din urmă caz, exercitarea dreptului la portabilitatea datelor personale nu poate fi acomodată cu prerogativele de control aparţinând altor persoane implicate, ceea ce impune, pe cale de consecinţă, refuzul legitim al operatorului de a da curs cererii de acces ori de portare a datelor ${ }^{17}$.

Dreptul la portabilitatea datelor este uzual descris ca reprezentând prerogativa persoanei vizate, de a recupera informaţiile cu caracter personal (pe care le-a furnizat unui operator), într-o formă structurată, utilizată curent, lizibilă automat în format digital, cu posibilitatea ca datele respective să fie transferate altui operator, operatorul căruia i-au fost furnizate iniţial datele fiind ţinut să nu obstaculeze prin blocaje inutile deplasarea, copierea sau, după caz, transmiterea

states a prevalence of right to erasure on the right to data portability"; fragmentul este preluat din lucrarea P. De Hert, V. Papakonstantinou, G. Malgieri, L. Beslay, I. Sanchez, op. cit., p. 198.

${ }^{14}$ Ibidem; autorii citați consideră, pornind de la sintagma "adversly exercised" prezentă în textul art. 20 RGDP, că: "It is irrelevant whether data portability affects other rights or freedoms; what is essential in this case is that this effect is not "adverse", e.g., it shall not create an unjustified damage or an illegitimate limitation to other rights or freedoms. In practice this means that judges will need to determine - on a case-by-case approach - when the right to data portability will adversely affect rights and freedom of others in a specific circumstance".

${ }^{15}$ S. Vezzoso, Data Portability: Initial Reflections on an Ex Ante Approach (March 26, 2020), [Online] la https://ssrn.com/abstract=3561413, accesat 08.11.2021.

${ }^{16}$ Ibidem.

${ }^{17}$ Pentru detalii pe marginea acestui subiect, a se consulta H. Vrabec, Unfolding the NewBorn Right to Data Portability: Four Gateways to Data Subject Control, SCRIPT-ed, 2018, [Online] la https://ssrn.com/abstract=3176820, accesat 08.11.2021; R. Walters, The Current Status of Data Portability in Personal Data and Competition Law, European Competition Law Review, 2020, [Online] la https://ssrn.com/abstract=3699807, accesat 08.11.2021. 
datelor cu caracter personal către alţi operatori de date ${ }^{18}$; dreptul la portabilitatea datelor personale este stratificat în câteva prerogative specifice, care pot fi decelate secvenţial, pe anumite paliere. Astfel, după cum s-a evidenţiat în literatura de specialitate ${ }^{19}$, dreptul de a primi datele într-un format portabil aparţine titularului, care poate conserva informaţiile pentru uz personal ori le poate transmite altui operator, dreptul de a obţine permutarea datelor exercitându-se fără ca operatorul precedent să aibă un drept de opoziţie relativ la exercitarea prerogativelor de portare. După cum s-a opinat, cu just temei, în doctrina de specialitate, în această manieră, „persoana vizată păstrează controlul asupra propriilor date, iar responsabilitatea operatorilor este consolidată. Aceleaşi date pot servi unor scopuri diferite ale prelucrării, în cazul unor servicii distincte, astfel că dreptul la portabilitate încurajează persoanele vizate să îşi recupereze datele şi să le reutilizeze"20.

Plasat sub o dublă limită, care îi permite prerogativei portabilităţii să depăşească rolul de „Cenuşăreasă” al reglementării din cuprinsul Regulamentului General, domeniul de aplicare al portabilităţii datelor cu caracter personal este restrâns, mai întâi, din punct de vedere subiectiv şi, simultan, obiectiv, întrucât portabilitatea priveşte datele cu caracter personal ce aparţin persoanei vizate; pot fi portate datele furnizate voluntar de către persoana vizată operatorului, în baza unui consimţământ de tip opting-in, care ulterior poate fi retractat, în principiu, în orice moment (cu excepţia datelor care rămân în continuare necesare pentru executarea obligaţiilor rezultate dintr-un contract aflat în curs de executare). Responsabilul prelucrării are obligaţia de a se conforma şi de a transmite datele solicitate, putându-se astfel configura arhitectura acestui drept de a obţine portarea datelor cu caracter personal, ca expresie a prerogativelor persoanei vizate de retractare a propriului consimţământ la prelucrare. În alţi termeni, dreptul de retractare a consimţământului la prelucrarea datelor personale, care ar fi de esenţa prelucrării bazate pe consimţământ în economia prevederilor RGDP, încapsulează inclusiv această prerogativă de a solicita şi de a obţine, pe cât posibil, recuperarea setului de date cu caracter personal (transmise, în mod activ şi conştient, operatorului, precum şi datele ce rezultă din activităţile subiectului), într-un format care ar permite reutilizarea acestora.

Sub aspectul consecinţelor exercitării acestui drept la portabilitate, posterior stabilirii dreptului persoanei vizate de a prelua controlul asupra datelor care o privesc, întrebarea evidentă (cu răspunsuri mai puţin evidente) se referă la conturarea unor repere clare cu privire la ceea ce presupune exerciţiul efectiv al acestui drept ${ }^{21}$. În temeiul dispoziţiilor art. 20 GDPR, persoana vizată are dreptul

${ }^{18}$ Grupul de lucru „Articolul 29” pentru protecţia datelor, „Ghid privind dreptul la portabilitatea datelor”, [Online] la https://www.dataprotection.ro/servlet/View Document? $\mathrm{id}=1383$, accesat 15.11.2021.

${ }^{19}$ C. Jugastru, „Dreptul la portabilitatea datelor”, loc. cit. supra.

${ }^{20}$ Ibidem.

${ }^{21}$ Inainte de a trece la enunțarea limitărilor existente, ar trebui să remarcăm succint că mecanismul de aplicare al Regulamentului general privind protecția datelor este așezat pe un trepied al remediilor juridice: neasigurarea portabilității datelor poate conduce la 
de a primi datele personale într-un format structurat, utilizat în mod curent şi care poate fi citit automat (răspuns care, după cum am specificat în paragrafele precedente, va fi emis în termen de o lună de la primirea cererii - conform dispoziţiilor art. 12, par. (3) RGDP). Formularea pentru care a optat legiuitorul european în textul art. 20 din Regulamentul General privind protecţia datelor cu caracter personal implică faptul că nu este suficient ca persoana vizată să poată extrage individual unele din aceste date personale ${ }^{22}$, strict secvenţial; mai degrabă, controlorul trebuie să furnizeze un set structurat de date, care să prezinte atributele de a putea fi considerat, din punct de vedere tehnic, un set portabil de date personale ${ }^{23}$. În ipotezele în care este fezabil din punct de vedere tehnic, persoana vizată poate solicita operatorului să transmită respectivele date într-o manieră directă, non-intermediată, altui operator, specificându-se în literatura de specialitate $^{24}$ că atât recepţia, cât şi transmiterea datelor cu caracter personal pot fi solicitate în orice moment al prelucrării datelor (anterior eventualei anonimizări), fiind, în principiu, exercitate cu titlu gratuit (cu excepţia unor costuri rezonabile care pot fi percepute pentru onorarea unor cereri repetitive de acces / de portare formulate de respectivul titular la intervale scurte de timp).

Pe marginea definirii noţiunii de interoperabilitate în acest context, al portării datelor cu caracter personal, în doctrina de specialitate s-a subliniat ${ }^{25}$ că regula

angajarea răspunderii civile a operatorului și, pe un palier secund, la un drept la despăgubiri în temeiul art. 82 RGDP, respectiv la impunerea de sancțiuni care intră în competențele Autorității Naţionale de Supraveghere a Prelucrării Datelor cu Caracter Personal (ANSPDCP).

${ }^{22}$ A se vedea P. De Hert, V. Papakonstantinou, G. Malgieri, L. Beslay, I. Sanchez, op. cit., p. 197; autorii citați subliniază că: "In sum, it becomes very clear that the right to data portability - in the final version of the GDPR - is composed of three different rights: 1) the right to receive (without hindrance from the data controller) data concerning data subject which he/she has provided; 2) the right to transmit (without hindrance from the data controller) those data to another controller; and 3) the right to have the personal data transmitted directly from one controller to another. While rights 1) and 2) can be exercised in any case where the processing is based on consent or on a contract and when the processing is carried out by automated means, right 3) needs one more condition: "where technically feasible". The format in which data should be transferred is "structured, commonly used and machine-readable", but the reference to "technical feasibility" is not related to the structured and machine-readable format, but to the "interoperability" of systems, as outlined in recital 68 of GDPR."

${ }^{23}$ D. Gill, W. Kerber, „Data Portability Rights: Limits, Opportunities, and the Need for Going Beyond the Portability of Personal Data”, loc. cit. supra.

${ }^{24}$ E. Bozdag, „Data Portability Under GDPR: Technical Challenges”, loc. cit. supra.

${ }^{25}$ P. De Hert, V. Papakonstantinou, G. Malgieri, L. Beslay, I. Sanchez, op. cit., p. 197; autorii citați evidențiază că: “As regards interoperability of systems, the European Commission has defined it as "the ability of disparate and diverse organisations to interact towards mutually beneficial and agreed common goals, involving the sharing of information and knowledge between the organisations, through the business processes they support, by means of the exchange of data between their respective ICT systems". Interoperability does not mean "compatibility", as recital 68 clarifies. At the same time, WP29 in its recent guidelines highlights that the determination of the interoperable formats is sector-specific." 
implică faptul că există formate de date utilizate în mod obişnuit pentru respectivele tipuri de date. Autorii care s-au ocupat de subiect au reţinut că, deşi acest aspect se poate dovedi adevărat pentru o multitudine de ipoteze, cu siguranţă, nu este aplicabil tuturor tipurilor de date personale; ar putea fi nominalizate, pentru exemplificare, reacţiile de tip like de pe o platformă de socializare sau datele captate de funcţiile smart ale unor dispozitive cu conţinut digital incorporat, în cazul cărora formatul utilizat pentru colectarea datelor personale ar putea fi incompatibil cu cel al altor dispozitive, în eventualitatea primirii unei cereri de portare. S-a susţinut mai degrabă că, într-o astfel de situaţie, operatorul poate îndeplini cerinţa de portabilitate furnizând datele în formatul utilizat la momentul prelucrării. De asemenea, nu este clar, invariabil, în practică despre cum urmează să fie determinat standardul de fezabilitate tehnică al unui transfer direct de date cu caracter personal, prin prisma faptului că un mecanism care este fezabil din punct de vedere tehnic pentru giganţi ai prelucrării datelor cu caracter personal poate fi dificil de implementat pentru controlorii de mai mici dimensiuni (de exemplu, clinici medicale de dimensiunii medii ca cifre de afaceri, care ar procesa date sensibile cu privire la care vor primi cereri de portare) şi care „trebuie să se bazeze pe un software dezvoltat şi susţinut de terţi." ${ }^{26}$ - (tr. n., J. G.).

\section{Remarci legate de interferenţele dintre reglementarea} dreptului la portabilitatea datelor conform prevederilor art. 20 RGDP şi dispoziţiilor Directivei 2019/770 privind furnizarea de conţinut digital şi servicii digitale

Binar în disjungerea pe care o operează între etapa executării contractului şi momentul începând cu care este exercitabil dreptul la portabilitatea datelor, sistemul de reglementare existent în cuprinsul Directivei 2019/770 privind anumite aspecte referitoare la contractele de furnizare de conţinut digital este centrat pe două dispoziţii privind portabilitatea conţinutului digital, regulile propuse distanţându-se de cele enunţate în textul art. 20 RGDP sub două aspecte semnificative, care pot fi decelate astfel: (1) în principiu, dreptul la portabilitatea conţinutului digital se aplică numai după rezilierea unui contract $\mathrm{B} 2 \mathrm{C}$ pentru furnizarea de conţinut digital sau, altfel spus, la încetarea acestuia, neexistând pe parcurs (în etapa derulării raporturilor contractuale B2C) în privinţa conţinutului digital (etapă în care ar putea fi, însă, exercitat dreptul la portarea nu a întregului conţinut digital disponibil, ci a datelor personale în temeiul art. 20 RGDP); (2) dreptul la portabilitate nu se limitează la datele cu caracter personal, ci se extinde, în textul Directivei 2019/770, asupra tuturor tipurilor de conţinut digital generate inclusiv prin înglobarea unor date cu caracter personal ale utilizatorilor.

Escamotând problematicile privitoare la valabilitatea clauzelor contractuale de amenajare a întinderii / sferei materiale a dreptului la portabilitatea conţinutului

${ }^{26}$ Ibidem. 
digital ${ }^{27}$, am putea reţine că Directiva adoptată în 2019 indică posibilitatea ca un contract $\mathrm{B} 2 \mathrm{C}$ privind furnizarea de conţinut digital să prevadă obligaţia corelativă a consumatorului, fie de a achita un preţ, care ar reprezenta contravaloarea serviciului digital furnizat, fie să ofere în mod asertiv contraprestaţii, altele decât sumele de bani, sub forma furnizării de date cu caracter personal. Condiţia prealabilă a furnizării „active” de date a fost criticată ca fiind vagă, insuficient de precisă, pentru a configura un regim juridic coerent ${ }^{28}$, şi anume din perspectiva faptului că datele care sunt colectate implicit de la consumator pe durata prestării unui serviciu digital vor prezenta adesea mai mult interes pentru furnizor decât datele pe care consumatorul le-a oferit în mod activ. Aserţiunea rămâne valabilă chiar şi în cazul în care consumatorul furnizează în mod activ date cu caracter personal, întrucât aceste date nu vor fi considerate a reprezenta o veritabilă contraprestaţie, dacă datele sunt strict necesare pentru executarea contractului sau pentru îndeplinirea cerinţelor legale, atât timp cât furnizorul nu utilizează datele pentru alte scopuri, în special cele comerciale sau scopuri de marketing personalizat. Pe cale de consecinţă, pot exista situaţii practice în care furnizarea de date personale cu ocazia prestării unui serviciu digital nu este considerată o contraprestaţie activă din partea consumatorului. $\mathrm{Cu}$ toate acestea, în practică, această exceptare va intra rareori în joc, deoarece datele despre consumatori sunt utilizate în mod regulat, ulterior, de către furnizorii serviciilor digitale în alte scopuri decât executarea efectivă a contractului, discuţia glisând în perimetrul advertising-ului personalizat, ceea ce transformă respectivele date într-o contraprestaţie furnizată de consumator, declanşând aplicabilitatea dispoziţiilor

${ }^{27}$ După cum s-a observat în doctrina de specialitate, "The distinction between data observed on the data subject and data created by the data controller is crucial to define the scope of the right to portability, but it is also one of the most difficult to make and requires case-by-case examination.” (s.n. - J.G.): M. Borghi, op. cit., p. 9. Dispozițiile Directivei 2019/770 se aplică, sub aspectul sferei materiale de incidență, contractelor între profesioniști și consumatori pentru furnizarea de conținut digital, cum ar fi fișiere video și audio, software, stocare în cloud, rețele sociale și fișiere de modelare vizuală pentru imprimare 3D, precum și jocuri, servicii e-mail, intermediere online de tranzacții și platforme de partajare, iar dispozițiile privind portabilitatea se vor aplica ori de câte ori normele de drept internaţional privat indică dreptul contractual al unui stat membru al UE (conform art. 4 și 6 din Regulamentul Roma I), ca fiind incident.

${ }^{28}$ A se vedea A. Metzger, „A Market Model for Personal Data: State of Play Under the New Directive on Digital Content and Digital Services", loc. cit. supra; autorul citat subliniază că: "According to the old paradigm, "free services" were offered to consumers who gave their consent to the processing of their data. Both transactions were seen as being independent of each other. The leading search engines, social media platforms and many "content" providers did not - and still do not - demand for a money consideration from the users. Those services therefore appeared as if they would be gratuitous for the consumer, whereas the service providers earned their revenues on the other side of the market by selling advertisements to business customers. The processing of the data, either based on consent or on the other legal grounds of Article 6 para. 1 General Data Protection Regulation (GDPR), was interpreted as an ancillary unilateral legal act besides the service contract". 
privitoare la portabilitatea datelor. Prevederile Directivei 2019/770, în versiunea finală a acestora, sunt aplicabile indiferent dacă un consumator furnizează datele personale în mod activ sau pasiv, având în vedere că formularea „furnizate în mod activ" din cuprinsul art. 3, alin. (1) şi alin. (2) a fost, în final, abandonată în textul Directivei. Cu toate acestea, rămâne de actualitate remarca potrivit căreia Directiva nu oferă o soluţie clară, specific calibrată pentru datele colectate de la un consumator pasiv; potrivit considerentului (24), este suficient ca datele cu caracter personal să fie „create” prin utilizarea conţinutului digital sau a serviciului digital, astfel încât chiar şi o simplă colecţie de meta-date, cum ar fi informaţiile referitoare la localizarea consumatorului sau istoricul de navigare poate fi suficientă, conform considerentului (25), pentru a reţine existenţa dreptului la portabilitate.

Cerinţa furnizării „active” a datelor prezintă, de asemenea, interes în mod indirect în ceea ce priveşte software-ul incorporat sau al produselor cu conţinut digital incorporat, o problematică ce suscită dezbateri suficient de ample în literatura de specialitate. În conformitate cu explicaţiile reţinute în Considerentul (11) al Directivei 2019/770, dispoziţiile privind vânzările online se aplică softwareului încorporat dacă funcţiile software-ului sunt subordonate principalelor funcţionalităţi ale produselor contractate şi funcţionează ca parte integrantă a produsului livrat, distincţie care a fost pe larg criticată în literatura de specialitate ${ }^{29}$. În ceea ce priveşte portabilitatea datelor, miza practică nu ar putea fi escamotată, fiind de reţinut că vânzătorul produsului cu conţinut digital incorporat sau furnizorul software-ului încorporat şi operatorul care colectează date prin intermediul software-ului încorporat vor fi adesea părţi diferite; de exemplu, în ipotezele în care obiectul derivat al vânzării îl reprezintă un dispozitiv cu funcţii smart (cu conţinut digital inclus), vânzătorul nu colectează de regulă datele generate prin utilizarea software-ului încorporat, acestea fiind colectate, în schimb, de către furnizorul sistemului de operare al dispozitivului smart. $\mathrm{Cu}$ toate acestea, dreptul de a prelua date cu caracter personal este activat numai dacă între consumator şi vânzătorul produsului cu conţinut digital incorporat a fost încheiat

${ }^{29}$ Ibidem; autorul citat evidențiază că: “The language of Article 3 para. 1 sub-para. 2 DCSD-Proposal was at the same time explicit and narrow. It was explicit that personal data or other data could be interpreted as counter-performance of the consumer which provoked the severe criticism of the European Data Protection Supervisor. However, the scope of application was rather narrow with regard to personal data that could qualify as counter-performance. Article 3 para. 1 sub-para. 2 only mentioned "actively provided" data. Recital 14 excluded data automatically generated and collected by cookies and also data "necessary for the digital content to function in conformity with the contract, for example geographical location where necessary for a mobile application to function properly", and data collected "for the sole purpose of meeting legal requirements". These restrictions were criticized both by academics and consumer organisations, a criticism that was finally taken up by the European Parliament which requested a broader inclusion of personal data into the framework of the Directive. The final text of Article 3 para. 1 sub-para. 2 DCSD addresses both concerns. The revised text avoids the words "personal data as counter-performance" to make clear that the European legislature does not encourage a further commercialisation of personal data.12 All the safeguards of the GDPR remain untouched, see Article 3 para. 8 and Recital 38 DCSD." 
un contract B2C, ceea ce ar implica ulterior că ar fi necesar să ţinem cont de existenţa şi arhitectura acestei relaţii tripartite, atunci când elaborăm sfera de aplicare a dreptului la portabilitatea datelor ${ }^{30}$.

Pe celălalt versant al discuţiei, conform dispoziţiilor art. 9 din Directiva 2019/770, privind integrarea incorectă a conţinutului digital sau a serviciului digital, „Orice neconformitate cauzată de integrarea incorectă a conținutului digital sau a serviciului digital în mediul digital al consumatorului este considerată ca reprezentând o neconformitate a conţinutului digital" dacă: (a) respectivul conţinut digital sau serviciu digital a fost integrat de către vânzătorul profesionist ori de subcontractanţi pentru care acesta răspunde; ori (b) conţinutul digital a fost destinat să fie integrat de consumator, iar integrarea incorectă s-a datorat unor deficienţe în instrucţiunile de integrare furnizate acestuia. După cum rezultă din paragrafele Considerentului (48) al Directivei 2019/770, nerespectarea obligaţiilor prevăzute în Regulamentul (UE) 2016/679 ar putea, în acelaşi timp, să implice per se o neconformitate a conţinutului digital sau a serviciului digital, făcându-l impropriu scopului său şi, prin urmare, să constituie o neconformitate raportat la cerințele obiective de conformitate, care impun ca serviciul digital să fie adecvat scopurilor tipice pentru care ar fi utilizat în mod uzual conţinutul digital sau serviciile digitale de acelaşi tip ${ }^{31}$. În fine, ar putea exista cazuri în care nerespectarea de către profesionistul vânzător a obligaţiilor care îi revin în temeiul Regulamentului (UE) 2016/679 poate constitui, de asemenea, o carenţă de conformitate a conţinutului digital sau a serviciului digital cu cerinţa obiectivă de conformitate care impune ca respectivul conţinut digital sau serviciul digital să aibă caracteristicile normale, tipice pentru conţinutul digital sau pentru serviciile digitale de acelaşi tip şi la care consumatorul se poate aştepta în mod rezonabil. De exemplu, în cazul în care profesionistul furnizor al unei aplicaţii de cumpărături online nu antamează măsurile prevăzute în Regulamentul (UE) 2016/679 pentru securitatea prelucrării datelor cu caracter personal ale consumatorului şi, în consecinţă, informaţiile privind cardul de credit / debit al consumatorului sunt expuse la programe malware sau spyware, aspect care ar putea constitui, de asemenea, o neconformitate a conţinutului digital sau a serviciului digital în sensul Directivei 2019/770, întrucât consumatorul s-ar aştepta, în mod rezonabil, ca o astfel de aplicaţie să prezinte by design caracteristici care să împiedice divulgarea detaliilor privind plăţile efectuate. În cazul în care aspectele care conduc la o nerespectare a cerinţelor prevăzute în Regulamentul (UE) 2016/679 constituie, de asemenea, o neconformitate a conţinutului digital sau a serviciului digital cu cerinţele subiective

${ }^{30} \mathrm{H}$. Vrabec, „The Failure of Control Rights in the Big Data Era - Does a Holistic Approach Offer a Solution?”, loc. cit. supra.

31 Astfel s-ar întâmpla, de exemplu, în cazul în care profesionistul care comercializează un software de criptare a datelor nu reușește să pună în aplicare măsurile adecvate impuse de Regulamentul (UE) 2016/679 pentru a se asigura că datele cu caracter personal din momentul conceperii nu sunt divulgate unor destinatari neautorizați, ceea ce ar face ca software-ul de criptare să nu fie adecvat scopului său, care este transferul în condiții de siguranță al datelor de către consumator către destinatarul preconizat. 
sau obiective de conformitate prevăzute în Directiva 2019/770, consumatorul ar urma să beneficieze de dreptul la măsurile corective în caz de neconformitate prevăzute de această directivă, cu excepţia cazului în care contractul este anulabil în temeiul dispoziţiilor de drept intern.

Sunt relevante, de asemenea, dispoziţiile art. 16, îndeosebi alin. 3, 4 şi 5 din Directiva 2019/770, privind obligaţiile vânzătorului / furnizorului în cazul încetării / terminării contractului, conform cărora „Furnizorul conţinutului digital ori al serviciului digital se va abţine pentru viitor, posterior încetării raporturilor contractuale cu consumatorul, de la utilizarea oricărui alt conţinut în afara datelor cu caracter personal care au fost furnizate sau create de consumator la utilizarea conţinutului digital sau a serviciului digital furnizat ${ }^{32}$.

$\mathrm{Cu}$ excepţia situaţiilor menţionate la alin. (3), lit. (a), (b) sau (c), din alin. (4) al art. 16 din Directiva 2019/770 rezultă că furnizorul conţinutului digital ori al serviciului digital „va pune la dispoziţia consumatorului, la cererea acestuia, orice conţinut care nu reprezintă date cu caracter personal, care a fost furnizat sau creat de către consumator în momentul utilizării conţinutului digital sau a serviciului digital", consumatorul având dreptul de a recupera respectivul conţinut digital întro manieră gratuită, non-oneroasă, fără costuri suplimentare / fără contraprestaţie şi fără impedimente din partea furnizorului conţinutului digital, într-un termen rezonabil şi într-un format utilizat în mod curent, care să poată fi citit automat întrun mediu digital. Din paragraful (5) al art. 16 din Directiva 2019/770 rezultă că furnizorul conţinutului digital ori al serviciului digital poate împiedica orice utilizare ulterioară a conţinutului digital sau a serviciului digital de către consumator, ,în special prin oprirea accesului consumatorului la conţinutul digital sau la serviciul digital sau prin dezactivarea contului de utilizator al consumatorului”, fără a aduce atingere prevederilor alin. (4) privitoare la portarea conţinutului generat.

Se menţionează în literatura de specialitate că, în contextul datelor furnizate, datele derivate (datele deduse) nu intră în sfera dreptului la portabilitate, „dar rămâne posibil pentru utilizator să solicite operatorului de date să îi comunice dacă datele sale au făcut sau nu obiectul prelucrării, iar în caz afirmativ, care au fost scopurile prelucrării" ${ }^{33}$. Ca principiu generic, nu fac obiectul portabilităţii datele care sunt prelucrate pe alte temeiuri decât cele menţionate de art. 20, alin. (1), lit. a), a căror prelucrare se fondează pe alte temeiuri decât consimţământul persoanei vizate ori nu sunt date personale necesare pentru executarea contractului. De asemenea, în principiu, portabilitatea nu presupune ştergerea datelor, întrucât, de exemplu, „nu presupune ştergerea datelor furnizate de persoana vizată în vederea

32 Sunt exceptate cazurile în care acest conținut: „(a) nu are vreo utilitate în afara contextului utilizării conținutului digital sau al serviciului digital furnizat de profesionist; (b) are legătură doar cu activitatea consumatorului atunci când folosește conținutul digital sau serviciul digital furnizat de vânzător; (c) a fost agregat cu alte date de către profesionist și nu poate fi dezagregat sau poate fi dezagregat numai cu eforturi disproporționate; (d) a fost generat în comun de către consumator și alte persoane vizate, iar alți consumatori pot continua să utilizeze conținutul.” (art. 16 DCDSD).

${ }^{33}$ C. Jugastru, „Dreptul la portabilitatea datelor”, loc. cit. supra. 
executării unui contract, în măsura în care datele respective sunt utile pentru executarea contractului” ${ }^{34}$. Se cuvine menţionat că portarea nu creează obligaţia responsabilului de a conserva datele pe o perioadă mai îndelungată decât cea prevăzută iniţial, în directă corelare cu scopurile prelucrării. Fezabilitatea tehnică a transmiterii de la un operator la altul, sub controlul persoanei vizate, va trebui evaluată în practică plecând de la circumstanţele fiecărui caz în parte. Considerentul (68) RGDP clarifică în continuare limitele a ceea ce este acceptabil din „punct de vedere tehnic“, indicând faptul că „nu ar trebui să genereze o obligaţie pentru operatori de a adopta sau de a menţine sisteme de prelucrare care să fie compatibile din punct de vedere tehnic" în ideea facilitării portării datelor cu caracter personal, astfel încât operatorilor de date personale nu le incumbă, în baza dispoziţiilor Regulamentului General, vreo obligaţie de adaptare a mecanismelor tehnice utilizate în scopul facilitării portării acestor date. În alţi termeni, merită accentuată aserţiunea conform căreia operatorilor nu le revine obligaţia de a adopta sau de a menţine sisteme de prelucrare care să fie compatibile din punct de vedere tehnic, prin prisma rezolvării eventualelor cereri de portare a datelor colectate şi prelucrate.

În pofida faptului că setul de meta-norme descris în art. 20 RGDP în materia portabilităţii datelor personale nu include obligaţia operatorilor de a compatibiliza programele software folosite, este de aşteptat ca operatorii să transmită date cu caracter personal într-un format interoperabil, cu toate că RGDP nu stabileşte obligaţii pentru alţi operatori în vederea sprijinirii acestor formate. Prin urmare, transmiterea directă de la un operator la altul ar putea apărea atunci când comunicarea între cele două sisteme este posibilă, într-un mod securizat, şi în cazul în care sistemul de primire a datelor are capacitatea, din punct de vedere tehnic, de a primi datele transmise. În situaţia în care obstacolele tehnice fac imposibilă transmiterea directă, operatorul trebuie să explice aceste impedimente persoanelor vizate, întrucât, în caz contrar, decizia sa va fi similară, în efectul său, unui refuz ${ }^{35}$ de a lua măsuri ca urmare a unei cereri a persoanei vizate conform dispoziţiilor art. 12 par. (4) din Regulamentul General.

\section{Paradigmatică, dar incertă: preeminenţa temeiurilor extrase din prevederile RGDP privind portabilitatea datelor}

În literatura de specialitate s-a ridicat problema de a stabili în ce măsură ar putea fi reţinută (in)existenţa unei preeminenţe a prevederilor RGDP privitoare la portabilitate, dacă un drept la portabilitate ia naştere, pentru consumator, atât în temeiul art. 20 RGDP, cât şi în temeiul prevederilor Directivei 2019/770 privind conformitatea conţinutului digital, în eforturile doctrinare de a răspunde interogaţiilor în ce măsură consumatorul poate alege pe ce regulă se bazează solicitarea sa de portare a datelor - sau chiar dacă îşi poate fonda cererea de portare pe ambele

\section{${ }^{34}$ Ibidem.}

${ }^{35}$ G. Nicholas, „Taking It With You: Platform Barriers to Entry and the Limits of Data Portability", loc. cit. supra. 
seturi de norme speciale, cumulând cele două mecanisme juridice privind portarea datelor cu caracter personal. Considerentele 37, 38 şi 39, precum şi dispoziţiile Art. 3, par. (6) şi (8) din Directiva 2019/770 clarifică faptul că regulile propuse în cadrul directivei nu aduc atingere normelor Regulamentului General privind protecţia datelor, subliniindu-se în doctrina de specialitate că ar fi logic ca niciuna dintre regulile de portabilitate să nu aibă prioritate faţă de cealaltă, deoarece dispoziţiile din Regulamentul general, respectiv din Directiva 2019/770 în materie de portabilitate prezintă atât particularităţi, cât şi o suprapunere semnificativă, rămânând să ţintească obiective de legiferare distincte. Dacă exigenţele legale intrinseci şi prerechizitele exogene (rezilierea unui contract B2C pentru furnizarea de conţinut digital sau încetarea acestui contract) pentru admisibilitatea unei cereri a consumatorului de portare a datelor personale sunt îndeplinite în temeiul dispoziţiilor Directivei 2019/770, consumatorul nu va trebui să recurgă suplimentar la prevederile RGDP, reciproca fiind de asemenea valabilă, prin prisma faptului că cele două reglementări nu se exclud (chiar dacă, parţial, sfera lor materială şi personală de executare rămâne a fi diferită). Pe de altă parte, în cazul în care unele dintre cerinţele aplicabile solicitării consumatorului de portare a datelor vor fi îndeplinite numai în temeiul art. 20 RGDP (transmiterea către un alt operator de date), iar alte cerinţe vor fi îndeplinite numai în cadrul remediilor neconformităţii descrise în prevederile Directivei 2019/770 (privind portabilitatea conţinutului digital, care încorporează parţial date personale), este util pentru consumator să asocieze şi o cerere distinctă privind portarea datelor personale fondată pe prevederile art. 20 RGDP. Mecanismul portării datelor personale în temeiul art. 20 RGDP rămâne, în continuare, util (şi chiar indispensabil) pe durata derulării raporturilor contractuale $\mathrm{B} 2 \mathrm{C}$ în privinţa conţinutului digital, când niciuna dintre părţi nu s-a prevalat de dreptul de a solicita rezilierea contractului, etapă în care ar putea fi exercitat dreptul la portarea nu a întregului conţinut digital disponibil, ci a datelor personale colectate şi prelucrate în temeiul consimţământului utilizatorului.

Existenţa unui contract B2C (de furnizare a conţinutului digital) în derulare se numără printre prerechizitele aplicării dreptului la portabilitate în temeiul prevederilor Directivei 2019/770, fără a o regăsi, însă, printre condiţiile indispensabile exercitării dreptului la portabilitate în temeiul art. 20 RGDP, ceea ce se coagulează ca o diferenţă majoră între sfera de aplicare ale acestui drept în economia dispoziţiilor DCSD şi, după caz, ale RGDP; cu toate acestea, întrebarea centrală se referă la a stabili dacă o situaţie în care consumatorul utilizează un serviciu digital fără a fi contractat în mod expres, de exemplu, în cazul în care iniţiază o căutare utilizând un motor de căutare online, prilej cu care furnizorii de servicii asociate utilizării motoarelor de căutare web colectează datele personale ale consumatorului ${ }^{36}$, trebuie sau nu calificate drept un veritabil contract $\mathrm{B} 2 \mathrm{C}$, aspect care nu a fost reglementat explicit în Directiva 2019/770, în contextul în care art. 3 reţine că Directiva privind contractele de furnizare a conţinutului digital „nu

\footnotetext{
${ }^{36}$ A se vedea A. Metzger, op. cit., p. 4.
} 
afectează libertatea statelor membre de a reglementa aspecte ale dreptului general al contractelor, precum regulile privind formarea, valabilitatea, nulitatea sau efectele contractelor”, urmând ca, la nivelul dispoziţiilor dreptului intern, să se tranşeze inclusiv răspunsul la interogaţiile ridicate pe acest palier, al (in)existenţei unui veritabil contract între utilizatorul serviciului web şi operatorul de date cu caracter personal.

Distincţia dintre consimţământul (in)valid şi cazurile de formare veritabilă a contractului privind furnizarea de conţinut digital sau servicii digitale în temeiul prevederilor Directivei 2019/770 prezintă, de asemenea, relevanţă $\breve{a ̆}^{37}$ pentru gestionarea corelaţiilor cu interdicţia prezentă în textul art. 7, alin. (4) RGDP, din perspectiva „cuplării” consimţământului la formarea contractului propriu-zis (de furnizare a conţinutului digital ori a serviciilor digitale, în acest caz) şi, pe de altă parte, a consimţământului la prelucrarea datelor cu caracter personal, inclusiv în contextul executării respectivului contract (un temei juridic per se al prelucrării datelor personale) ${ }^{38}$. „Decuplarea” celor două consimţăminte (la prelucrarea datelor personale şi, respectiv, la formarea contractului B2C) este elementară în economia noţiunii de „consimţământ liber furnizat” prin prisma prevederilor art. 7, par. (4) RGDP, din care rezultă că va fi folosit drept criteriu decisiv în evaluarea libertăţii de a consimţi la prelucrarea datelor cu caracter personal în contextul contractării B2C. În literatura de specialitate ${ }^{39}$, a fost remarcată utilizarea sintagmei (edulcorate) „se ține seama cât mai mult de faptul că, printre altele, executarea unui contract (...)"40, ceea ce imprimă un anumit grad de flexibilitate în utilizarea acestui criteriu, în pofida „vestimentaţiei” de aparentă interdicţie imperativă a oricărei combinaţii de tipul asocierii consimţământului la prelucrarea datelor personale (i) şi a acordului la formarea şi executarea contractului (substanţial) (ii); strict tehnic, chiar şi în ipotezele în care ar rezulta că acordul utilizatorului la colectarea şi prelucrarea datelor sale personale ar fi invalid prin prisma dispoziţiilor art. 7, par. (4) RGDP, din pricina condiţionării acestui acord într-o manieră incompatibilă cu caracterul liber exprimat, contractul de furnizare a conţinutului digital ar rămâne valabil format, fiind incidente, în acest caz, prevederile Directivei 2019/770, inclusiv cu privire la portabilitatea datelor la finele raporturilor contractuale.

${ }^{37}$ Idem, p. 7.

38 Potrivit prevederilor art. 7, par. (4) RGDP, „(4) Atunci când se evaluează dacă consimțământul este dat în mod liber, se ține seama cât mai mult de faptul că, printre altele, executarea unui contract, inclusiv prestarea unui serviciu, este condiționată sau nu de consimțământul cu privire la prelucrarea datelor cu caracter personal care nu este necesară pentru executarea acestui contract.”

${ }^{39}$ A se vedea A. Metzger, op. cit., p. 7.

${ }^{40}$ Idem, p. 8; autorul citat evidențiază, în termeni tranșanți, că, în cele din urmă, reprezintă o chestiune de interpretare a (clauzelor neclare ale) contractului: "If and to what extent a consumer has an obligation to provide personal data under a contract and to give its consent in the processing of that data, or whether the processing of data is a mere side-effect of the contract, is first and foremost a question of contract interpretation." 
Aceleaşi principii rămân incidente şi în cazul retragerii ulterioare a consimţământului persoanei vizate la prelucrarea datelor personale, potrivit art. 7, par. (3) RGDP, persoana vizată putându-şi retrage consimţământul la prelucrarea datelor personale în orice moment (fără ca retragerea consimţământului să afecteze legalitatea prelucrării bazate pe consimţământ anterior retragerii acestuia), în timp ce, dimpotrivă, retragerea consimţământului care a generat formarea contractului de furnizare a unor servicii digitale nu poate avea loc într-o manieră unilaterală, ca regulă generală fiind aplicabil mutuus dissensus, chiar dacă rămâne posibilă invocarea carenţelor de neconformitate pentru a obţine rezoluţiunea / rezilierea judiciară a contractului; ceea ce rămâne de decelat în temeiul art. 7, alin. (3) RGDP este răspunsul la interogaţia cu privire la consecinţele retragerii acordului utilizatorului la prelucrarea datelor sale cu caracter personal, prelucrarea ulterioară a acestora rămânând posibilă că fondată pe necesitatea executării contractului, fără a mai avea ca fundament consimţământul utilizatorului.

Eboşa astfel trasată trebuie întregită cu trimiterile la prevederile art. 3, alin. (1), teza a II-a din Directiva 2019/770, care menţionează că dispoziţiile Directivei devin inaplicabile în cazul în care datele cu caracter personal sunt prelucrate exclusiv de comerciant în scopul furnizării de conţinut digital sau servicii digitale sau pentru a permite comerciantului să respecte cerinţele legale la care este supus în această materie, iar comerciantul nu procesează aceste date personale în orice alt scop. Pe cale de consecinţă, aplicarea dispoziţiilor Directivei 2019/770 nu poate fi reţinută în ipotezele în care prelucrarea datelor personale se bazează pe art. 6, alin. (1), lit. b) şi c) din RGDP, precum în cazul, de exemplu, în care un serviciu de navigaţie rutieră prelucrează datele de locaţie cu unicul scop de a recomanda traseul adecvat către consumator; este fastidios de amintit că, în aceste cazuri, prelucrarea datelor personale trebuie să rămână cantonată între limitele descrise de scopurile menţionate, în caz contrar, fiind aplicabil setul de norme din cuprinsul Directivei 2019/770 privind furnizarea de conţinut digital ${ }^{41}$.

\section{Remarci concluzive}

Erodat, în practică, de eventuala incompatibilitate tehnică între formatele de portare utilizate, mecanismul portabilităţii datelor cu caracter personal prezintă o utilitate indeniabilă, inclusiv în perimetrul executării contractelor de furnizare a conţinutului digital şi de prestare a serviciilor digitale. Domeniul de aplicare al portabilităţii datelor cu caracter personal este restrâns, mai întâi, din punct de vedere subiectiv şi, simultan, obiectiv, întrucât portabilitatea priveşte datele cu

${ }^{41}$ Ibidem; autorul citat reține că: "Regrettably, the DCSD does not provide a clear-cut rule for cases in which the processing of data is based on Article 6 para. 1 lit. f) GDPR, i.e. is "necessary for the purposes of the legitimate interests pursued by the controller or by a third party", or on other statutory grounds, Article 6 para. 1 lit. e), para. 2 GDPR. The issue is of growing interest, especially if one shares the criticism of consent as the commonly used basis of data processing. 42 Lengthy "data policies" and "privacy statements" do indeed, as put forward by the critics, prevent the consumer from taking an informed decision". 
caracter personal ce aparţin persoanei vizate; pot fi portate datele furnizate voluntar de către persoana vizată operatorului, în baza unui consimţământ de tip opting-in, care ulterior poate fi retractat, în principiu, în orice moment (cu excepţia datelor care rămân în continuare necesare pentru executarea obligaţiilor rezultate dintr-un contract aflat în curs de executare). Responsabilul prelucrării are obligația de a se conforma şi de a transmite datele solicitate, putându-se astfel configura arhitectura acestui drept de a obţine portarea datelor cu caracter personal, ca expresie a prerogativelor persoanei vizate de retractare a propriului consimţământ la prelucrare.

La fel cum gambitul damei poate fi acceptat sau poate fi refuzat de către jucător, „gambitul” propus de utilizator prin angajarea portabilităţii datelor sale personale în temeiul prevederilor Directivei 2019/770 anterior încetării contractului prin reziliere / anterior desfiinţării raporturilor contractuale poate fi refuzat de operatorul de date (furnizorul de servicii digitale), în timp ce o eventuală cerere de portare fondată pe prevederile art. 20 RGDP nu ar putea fi contracarată niciun moment de către operatorul de date, nefiind permisă plasarea de obstacole nerezonabile în exercitarea acestor prerogative ale persoanei vizate. Spre deosebire de gambitul regelui, în gambitul damei, pionul este fie recâştigat, fie va fi menţinut lângă piesele negre; pentru utilizatorul serviciilor digitale, invocarea prevederilor art. 20 RGDP rămâne utilă dacă doreşte să obţină transmutarea datelor cu caracter personal într-un format portabil până la momentul rezilierii contractului de furnizare a conţinutului digital / serviciilor digitale, moment de la care s-ar putea prevala de dispoziţiile Directivei 2019/770 pentru a obţine portarea datelor / fişierelor încărcate ori create cu ajutorul conţinutului digital contractat, incluzând eventualele date $\mathrm{cu}$ caracter personal astfel utilizate. Următoarele observaţii concluzive pot fi formulate, pe marginea consideraţiilor din secţiunile precedente:

(a) portabilitatea datelor se bifurcă în dreptul unei persoane fizice „de a primi datele cu caracter personal care o privesc şi pe care le-a furnizat operatorului întrun format structurat, utilizat în mod curent şi care poate fi citit automat" (i) şi, pe celălalt versant, în dreptul de a transmite aceste date altui operator, fără obstacole nejustificate din partea operatorului căruia i-au fost furnizate datele cu caracter personal (ii), fiind, din start, excluse din sfera materială de incidenţă a acestui drept datele anonimizate sau datele care nu privesc utilizatorul care solicită accesul la datele sale;

(b) datele pseudonimizate, care, prin definiţie, pot fi folosite pentru a identifica utilizatorul, chiar dacă identificarea se face cu ajutorul unor chei de decriptare, rămân să facă obiectul dreptului la portarea datelor, pseudonimizarea nereprezentând per se un obstacol în calea exercitării acestor prerogative;

(c) în ipotezele în care este fezabil din punct de vedere tehnic, persoana vizată poate solicita operatorului să transmită respectivele date într-o manieră directă, non-intermediată, altui operator, astfel încât atât recepţia, cât şi transmiterea datelor cu caracter personal pot fi solicitate în orice moment al prelucrării datelor (anterior eventualei anonimizări), fiind, în principiu, exercitate cu titlu gratuit, cu 
excepţia perceperii unor costuri rezonabile pentru onorarea unor cereri repetitive de acces / de portare;

(d) clivajul semnalat între regimul portabilităţii datelor personale în temeiul dispoziţiilor art. 20 RGDP şi regimul portabilităţii conţinutului digital reglementat de prevederile Directivei 2019/770 este adâncit de faptul că, în principiu, dreptul la portabilitatea conţinutului digital se aplică numai după rezilierea unui contract B2C pentru furnizarea de conţinut digital sau, altfel spus, la încetarea acestuia, neexistând pe parcurs (în etapa derulării raporturilor contractuale B2C) în privinţa conţinutului digital (etapă în care ar putea fi, însă, exercitat dreptul la portarea nu a întregului conţinut digital disponibil, ci a datelor personale în temeiul art. 20 RGDP);

(e) dreptul la portabilitatea conţinutului digital nu se limitează la datele cu caracter personal încorporate în conţinutul digital propriu-zis, ci se extinde, în textul Directivei 2019/770, asupra tuturor tipurilor de conţinut digital generate / create inclusiv prin înglobarea unor date cu caracter personal ale utilizatorilor;

(f) obligaţia utilizatorului de a furniza date cu caracter personal ar putea ridica probleme de calificare drept contraprestaţie a consumatorului, în sensul unui raport contractual sinalagmatic, aspect amintit mai degrabă aluziv, însă netranşat expres în cuprinsul Directivei 2019/770 privind contractele de furnizare a conţinutului digital; în principiu, revine legiuitorului naţional tranşarea acestei problematici în legătură cu consecinţele unei posibile neexecutări contractuale, îndeosebi în perimetrul situaţiilor în care s-ar ridica problema de a stabili în ce măsură refuzul consumatorului de a furniza datele sale personale ar putea justifica un refuz similar al profesionistului de a furniza conţinutul digital şi în ce măsură ar putea justifica o solicitare de reziliere a contractului de furnizare a serviciilor digitale.

\section{Referinţe}

Aertgeerts, P., Shaping Fundamental Rights: The Right to Data Portability, the EU Legislator and the Normative Foundations of the Fundamental Right to Data Protection (November 6, 2019)

Alberini, A.; Benhamou, Y., Data Portability and Interoperability: An Issue that Needs to Be Anticipated in Today's It-Driven World (August 1, 2017), https://dx.doi.org/10.2139/ ssrn.3038877

Araújo Souto, G., Data Portability: a Necessary Right for Users and Competitors of Digital Platforms (October 12, 2018), https://dx.doi.org/10.2139/ssrn.3293056

Banda, C., Enforcing Data Portability in the Context of EU Competition Law and the GDPR, MIPLC Master Thesis Series 2017

Belo, J.; Macedo Alves, P., The Right to Data Portability: An In-Depth Look, Journal of Data Protection and Privacy, Vol. 2, nr. 1/2018

Borghi, M., Data Portability and Regulation of Digital Markets, CIPPM / Jean Monnet Working Papers, Bournemouth University, 2019, https://dx.doi.org/10.2139/ ssrn.3617792

Bozdag, E., Data Portability Under GDPR: Technical Challenges (January 28, 2018), https://dx.doi.org/10.2139/ssrn.3111866

De Hert, P.; Papakonstantinou, V.; Malgieri, G.; Beslay, L.; Sanchez, I., The Right to Data Portability in the GDPR: Towards User-Centric Interoperability of Digital Services, Computer Law \& Security Review, 2018 
De Streel, A.; Kraemer, J.; Senellart, P., Making Data Portability More Effective for the Digital Economy (June 14, 2021), https://dx.doi.org/10.2139/ssrn.3866495

Gill, D.; Kerber, W., Data Portability Rights: Limits, Opportunities, and the Need for Going Beyond the Portability of Personal Data (October 11, 2020), https://dx.doi.org/ 10.2139/ssrn.3715357

Graef, I., The Opportunities and Limits of Data Portability for Stimulating Competition and Innovation, Competition Policy International, Antitrust Chronicle November 2020 (II)

Graef, I.; Husovec, M.; van den Boom, J., Spill-Overs in Data Governance: The Relationship Between the GDPR's Right to Data Portability and EU Sector-Specific Data Access Regimes, TILEC Discussion Paper No. DP 2019-005, 2019, https://dx.doi.org/10.2139/ssrn.3369509

Graef, I.; Clifford, D.; Valcke, P., Fairness and Enforcement: Bridging Competition, Data Protection and Consumer Law, International Data Privacy Law, vol. 8, nr. 3/2018

Graef, I.; Husovec, M.; Purtova, N., Data Portability and Data Control: Lessons for an Emerging Concept in EU Law, German Law Journal, vol. 19, nr. 6/2018, pp. 1359-1398, Tilburg Law School Research Paper No. 2017/22, https://dx.doi.org/10.2139/ssrn.3071875

Hurwitz, J., Digital Duty to Deal, Data Portability, and Interoperability, The Global Antitrust Institute Report on the Digital Economy 28, 2020, https://dx.doi.org/10.2139/ssrn. 3733744

Jugastru, C., Dreptul la portabilitatea datelor, Revista Universul Juridic, disponibil la adresa http://revista.universuljuridic.ro/dreptul-la-portabilitatea-datelor/, on-line

Ke, T.; Sudhir, K., Privacy Rights and Data Security: GDPR and Personal Data Driven Markets (July 5, 2020), https://dx.doi.org/10.2139/ssrn.3643979

Kraemer, J., Personal Data Portability In The Platform Economy: Economic Implications And Policy Recommendations, Journal of Competition Law \& Economics, 2020

Leistner, M., The Existing European IP Rights System and the Data Economy - An Overview With Particular Focus on Data Access and Portability, în J. Drexl (ed.), „Data access, Consumer Protection and Public Welfare”, Nomos, 2020, https://dx.doi.org/10.2139/ ssrn. 3625712

Leonard, P., Regulatory Trends and Emerging Practices in Access to Customer Data, Portability and Data Sharing in the Financial Services Sector (December 3, 2017)

Lisievici, A., Dreptul la portabilitatea datelor potrivit Regulamentului General privind Protecţia Datelor, în I. Alexe, D.-N. Ploeşteanu, D.-M. Şandru, „Protecţia datelor cu caracter personal. Impactul protecţiei datelor personale asupra mediului de afaceri. Evaluări ale experienţelor româneşti şi noile provocări ale Regulamentului (UE) 2016/679”, Editura Universitară, Bucureşti, 2017

Metzger, A., A Market Model for Personal Data: State of Play Under the New Directive on Digital Content and Digital Services (August 4, 2020). in Lohsse S., Schulze R., Staudenmayer D. (eds.), „Data as Counter-Performance - Contract Law 2.0?” Münster Colloquia on EU Law and the Digital Economy V, 2020

Monteleone, A. G., Il Diritto Alla Portabilità Dei Dati. Tra Diritti Della Persona e Diritti Del Mercato, LUISS Law Review, 2/2017

Nicholas, G., Taking It With You: Platform Barriers to Entry and the Limits of Data Portability, Michigan Telecommunications and Technology Law Review, 2020

Swire, P., The Portability and Other Required Transfers Impact Assessment: Assessing Competition, Privacy, Cybersecurity, and Other Considerations, Georgia Tech Scheller College of Business Research Paper No. 3689171, 2020, https://dx.doi.org/10.2139/ ssrn. 3689171 
Turner, S.; Galindo Quintero, J.; Lis, J.; Tanczer, L., The exercisability of the right to data portability in the emerging Internet of Things (IoT) environment (September 26, 2021), https://dx.doi.org/10.2139/ssrn.3931040

Vezzoso, S., Competition Policy in Transition: Exploring Data Portability's Roles, 15th ASCOLA Conference, 25-27 June 2020https://dx.doi.org/10.2139/ssrn.3634736

Vezzoso, S., Data Portability: Initial Reflections on an Ex Ante Approach (March 26, 2020), https://dx.doi.org/10.2139/ssrn.3561413

Vrabec, H., Unfolding the New-Born Right to Data Portability: Four Gateways to Data Subject Control, SCRIPT-ed, 2018

Vrabec, H., The Failure of Control Rights in the Big Data Era - Does a Holistic Approach Offer a Solution?, in Bakhoum, M., Gallego Conde, B., Mackenordt, M.-O., Surblyte, G. (eds.) „Personal Data in Competition, Consumer Protection and IP Law - Towards a Holistic Approach?”, Berlin Heidelberg: Springer, 2017

Walters, R., The Current Status of Data Portability in Personal Data and Competition Law, European Competition Law Review, 2020

Grupul de lucru „Articolul 29” pentru protecţia datelor, „Ghid privind dreptul la portabilitatea datelor”, on-line 